\title{
LA PUERTA DE LATINOAMÉRICA (DESDE LAS RUTAS ARGENTINAS): SAN SALVADOR DE JUJUY EN GEOGRAFÍAS AUDIOVISUALES AMPLIAS
}

\author{
Latin American gate (from Argentine routes): \\ San Salvador de Jujuy in broad audio-visual geographies
}

Alejandra García Vargas*

\section{Resumen}

¿Qué significa estar ubicada en lugares particulares, cuando ese lugar es una provincia argentina noroestina y de frontera, cuando tal ubicación se interroga a partir de los sentidos de ciudad que ofrecen narrativas audiovisuales locales, y cuando esa interrogación busca analizar una configuración cultural conmocionada por el debate en torno a la redistribución del poder de visibilizar el orden social y sus conflictos mediante la audiovisualización televisiva?

La investigación-marco de este ensayo aborda la conflictividad de lo social expresada en las interpretaciones heterogéneas, históricas, conflictivas y contingentes sobre la ciudad (como espacio en común), que construyen diversos actores, en desiguales condiciones, para comprender su experiencia urbana. Estos sentidos de ciudad, como parte del sentido común o como formas coherentes que lo combaten, participan de las disputas culturales en torno a las relaciones y posiciones sociales vinculadas a la región audiovisual que se abordan en este trabajo.

$<$ Narrativas audiovisuales $><$ Sentidos de ciudad $><$ Configuraciones culturales $><$ Jujuy-NOA $>$

\begin{abstract}
What does it mean to be located in particular places, when said place is an Argentine border province, when such a location is questioned on the basis of the senses of city offered by local audio-visual narratives, and when that question seeks to analyse a cultural configuration shocked by the debate around the redistribution of the power of visualising the social order and its conflicts through televisual audio- visualisation?

The research framework of this essay addresses, the level of conflict in the social realm, expressed in the heterogeneous, historical, conflictive and contingent interpretations of the city (as a common space), by various actors in unequal conditions in order to construe in unequal conditions, in order to construe their urban experience. These senses of city, either as part of common sense or as coherent forms that fight it, are part of the cultural disputes around social relations and positions related to audio-visual region explored in this work.

$<$ Audiovisual narratives $><$ Senses of city $><$ Cultural configuration $><$ Jujuy, argentine north west region $>$

Recibido: 01/10/2017 // Aceptado: 10/12/2017

\footnotetext{
* Licenciada y Doctora en Comunicación Social, Universidad Nacional de Córdoba. Docente-investigadora y profesora adjunta ordinaria (FHyCS, UNJu y FH, UNSa), codirectora del Centro de Estudios Socioeconómicos para el Desarrollo con Equidad (FCE-UNJu), directora y codirectora de proyectos categoría "A" (UNICCS/ SECTER-UNju y CIUNSa). Universidad Nacional de Jujuy y Universidad Nacional de Salta. alegarciavargas@gmail.com
} 
García Vargas. La puerta de Latinoamérica (desde las rutas Argentinas): San Salvador de Jujuy en geografías...

La cultura es un hacer reflexivo que produce nociones en base a las que ciertos aspectos se naturalizan y definen como a-culturales, mientras algunos se marcan como atributo particular de ciertos otros, o se enfatizan como propios, o incluso se desmarcan como generales o compartidos

Claudia Briones $(2005,15)$

¿Qué significa estar ubicada en lugares particulares, cuando ese lugar es una provincia argentina noroestina y de frontera, cuando tal ubicación se interroga a partir de los sentidos de ciudad que ofrecen narrativas audiovisuales locales, y cuando esa interrogación busca analizar una configuración cultural conmocionada por el debate en torno a la redistribución del poder de visibilizar el orden social y sus conflictos mediante la audiovisualización televisiva?

Este ensayo se desprende de un trabajo mayor que se estructuró en torno a esta pregunta general y buscó responderla a partir del análisis de sentidos de ciudad en Jujuy, específicamente de aquellos ofrecidos por narrativas televisivas locales, producidas y emitidas (o alojadas y puestas a disposición en línea en plataformas específicas) en un momento particular de la dinámica audiovisual argentina, caracterizado por la disponibilidad de convocatorias para participar en políticas de fomento a la producción para la televisión digital abierta (García Vargas, 2017).

Estos sentidos de ciudad, como parte del sentido común o como formas coherentes que lo combaten, participan de las disputas culturales en torno a las relaciones y posiciones sociales vinculadas a la construcción de una región audiovisual. Es por ello que, en este trabajo, me detengo en algunos aspectos regionalizados y regionalizantes de esos conflictos, expresados en las interpretaciones heterogéneas, históricas, conflictivas y contingentes que construyen diversos actores, en desiguales condiciones, para comprender su experiencia de estar ubicados o ubicadas en una ciudad capital provincial del Noroeste argentino.

La perspectiva teórica se basa en la literatura que enfatiza el carácter de producción social del espacio, resalta el carácter constituyente de la cultura en ese proceso y vincula a ambos con específicas geografías del poder (Lefebvre, 2013; Williams, 1997; Massey, 1995). Desde allí, se especifica la mirada al espacio urbano y a los paisajes audiovisuales contemporáneos, para analizar los sentidos de ciudad circulantes en San Salvador de Jujuy durante el período de debate sobre los servicios de comunicación audiovisual y su relación con "la" cultura nacional argentina asociados a las políticas públicas para la televisión digital entre 2010 y 2015.

Doreen Massey y Pat Jess (2003) retoman la célebre frase de Marx sobre la historia e indican que "es la propia gente la que hace los lugares, pero no siempre en circunstancias que ella misma haya elegido". Con relaciones, circunstancias y la propia gente las autoras refieren a hombres y mujeres desigualmente situados en un juego constante de límites y presiones para dar sentido a su experiencia de estar ubicados o ubicadas en lugares particulares, un juego que al mismo tiempo forma parte de la producción social del 
espacio. Las interpretaciones recibidas y las experiencias urbanas prácticas que informan las emociones y razones cotidianas sobre la ciudad de hombres y mujeres situados social y espacialmente se traducen en "sentidos de ciudad" que toman forma, en gran medida, por las circunstancias sociales, culturales y económicas en las que se encuentran las personas, pero que no se limitan a reproducirlas, sino que también generan otras nuevas. Es así que se producen y circulan en una trama de relaciones de poder, desigualdad y resistencia espacializada y espacializante, a la que a su vez alimentan.

Los sentidos de ciudad se producen narrativamente en situaciones específicas y revelan relaciones asimétricas de poder. En este caso, abordaremos los sentidos de ciudad de un conjunto de programas producidos localmente, y los de sus productores y productoras, como parte de la tarea de describir la interrelación entre diferentes "sentidos de ciudad" que informan y se producen en los distintos "nódulos" de la vida social de la TV (Abu-Lughod, 2006). Estas narrativas remiten a distintas situaciones, actores y momentos del proceso comunicacional mediatizado, que no sólo están "localizados", sino que también espacializan. El análisis contribuirá a observar los conflictos, movimientos, distancias, confluencias, sedimentaciones y formas de legitimación que ponen en relación a la ciudad y a los ámbitos regionales.

Efectivamente, los sentidos de ciudad se conforman a partir de elementos diversos e incluyen tanto los recuerdos y las experiencias cotidianas personales de la interacción y la relación con otros y otras como el sentido común sedimentado sobre lugares, personajes y relaciones. La narración permite "elaborar -de manera comunicable a otro- fragmentos de esas complejas conexiones de lo inconmensurablemente vivido" (Lindón, 2008, s/p.).

Las narrativas construidas por los programas seleccionados, sus realizadores y realizadora brindan un punto de abordaje situado de las dinámicas de la comunicación/ cultura contemporánea en una coyuntura de transformación particular, que describiré brevemente en el primer apartado. En los términos indicados, permiten comprender tanto a la ciudad como a la cultura, pues interrogan las disputas en torno a qué significa estar ubicado o ubicada en lugares particulares, qué distintas modalidades de pertenencia son posibles y de qué diversas formas se vinculan las personas entre sí y con el mundo. Es decir, permiten recoger la inquietud de Grossberg (1996) sobre la necesidad de atender a la dimensión espacial en los estudios culturales.

Metodológicamente, se realiza un ejercicio interpretativo que reúne diversas estrategias en el marco del análisis cultural (Sautu, 2005; Papalini, 2010), para dar cuenta de las articulaciones entre espacios, temporalidades y ejes de identificación de actores/actrices sociales, a partir de materiales concretos provenientes de trabajo de campo (García Vargas, 2006).

Un conjunto de cuatro programas televisivos operan como punto de ingreso a ese ejercicio y combinan tres importantes características en común: la audiovisualización de espacios públicos de San Salvador de Jujuy; la localización y el período de registro y producción, en tanto dimensiones de la situacionalidad compartida. Al mismo tiempo, ofrecen heterogeneidad en géneros, en formatos y en otros componentes de las situaciones productivas (por ejemplo, las formas del financiamiento o la relación con las 
García Vargas. La puerta de Latinoamérica (desde las rutas Argentinas): San Salvador de Jujuy en geografías...

instituciones que regulan los circuitos de distribución). Es así que se trabajó a partir de la serie de ficción El viaje, 9 días buscando Norte (Vargas, 2011); el unitario documental San Salvador de Jujuy, Murmullo que aturde (Ricciardi, 2011); la serie documental Maestros del Norte (Ogando, 2011) y el magazine cultural semanal Jujuy Profundo (Calvetti, 2012). ${ }^{1}$ La combinación de elementos homogéneos y heterogéneos en el conjunto referido buscó concordancias y discrepancias significativas en el material, que permitiesen analizar un "sentido común" sobre la ciudad y las disputas hegemónicas en torno a su construcción, consolidación, contestación o sostenimiento.

El trabajo de campo se realizó de 2011 a 2015, se orientó a registrar y analizar narrativas de los realizadores/as de los programas seleccionados que combinaran itinerarios sociobiográficos y profesionales y representaciones sobre la ciudad, la región y la nación. En base a entrevistas con miembros de cada equipo de realizadores/as, se recuperaron los sentidos de ciudad vinculados a las situaciones de producción de cada serie o ciclo. Esta tarea se aproxima al método etnográfico de análisis de situaciones tal como lo explica Sautu (2005), y es la que alimenta específicamente este ensayo. Se realizaron seis entrevistas en profundidad, a cinco realizadores y una realizadora locales ${ }^{2}$ :

- JoV: es el director de El viaje.

- FeB: es el guionista de El viaje.

- DiR: es el director de Murmullo y el productor de Maestros del Norte.

- ArO: es el director de Maestros del Norte y el productor de Murmullo.

- PaK: es la asistente de dirección de Murmullo y de Maestros.

- FeC: es periodista, conductor y productor general de Jujuy Profundo.

El material analizado en el proyecto-marco mencionado indica que los sentidos de ciudad se producen por identificación con la ciudad (con los que se presentan como sus "rasgos específicos" y hacen de ella una ciudad) y por oposición contra otros sitios y ciudades (en las actividades de "pareo" que la presentan como otra ciudad), pero también por el peso relativo que se le asigna en términos de continuidades espaciales amplias que invocan las mediaciones, intersecciones y superposiciones involucradas

1 En el anexo, se presenta una tabla sintética que resume las características de los programas.

2 El director de El viaje nació en Jujuy, realizó el trayecto formativo universitario en Cine en Córdoba y al regresar hizo numerosos trabajos en la Quebrada y Puna, conservando la residencia en San Salvador de Jujuy. El guionista de esa serie nació en Buenos Aires, donde realizó todo su trayecto educativo completando una licenciatura en Comunicación Social, se trasladó a Tartagal para trabajar, luego a San Salvador de Jujuy en un período profesional extenso que combinaba su tarea en producción audiovisual con docencia universitaria en Salta, hizo el doctorado con una beca en España, y actualmente reside en Tucumán. El director de Murmullo nació en Neuquén, realizó el trayecto formativo universitario en Buenos Aires, se trasladó a Tilcara (Jujuy) para luego completar la universidad (Comunicación Social) y residir en San Salvador de Jujuy. El productor de ese unitario nació en Buenos Aires, en la infancia se trasladó a Jujuy, junto a su familia y en el marco del movimiento de "exilio interno" correspondiente a la última dictadura argentina, reside en San Salvador de Jujuy, donde realizó su formación escolar y universitaria en Antropología, con trayectos formativos y profesionales cortos en España, diferentes países de Latinoamérica y otros puntos del país. La asistente de producción de esa serie nació en Rafaela y se trasladó a Jujuy luego de terminar la formación universitaria. El realizador de Jujuy Profundo nació y realizó todo su trabajo profesional en el campo periodístico en San Salvador de Jujuy. 
en todo hecho de contacto (al invocarse como esta ciudad, entre otros sitios y en tanto parte de un mapa mayor e histórico que le brinda sentido).

En este ensayo me interesa explorar el último punto: los sentidos de ciudad que emergen del lugar relativo que ocupa San Salvador de Jujuy dentro de geografías culturales amplias (Agüero y García, 2010) vinculadas a intercambios y contactos históricos y conflictivos. Propongo pensar que los sentidos de ciudad no sólo se producen desde aquellos procesos que permiten darles forma en términos de la identidad y la diferencia que emergen de la consideración de sus atributos inmanentes (la descripción de características "propias", si bien complejas y en disputa) o de la contrastación con otros sitios (los pareos de contraste con el mundo andino, con las imágenes dominocéntricas de la nación, o con otras ciudades que se presumen modélicamente argentinas para brindar sentido a la propia experiencia urbana en diálogo con el sentido común), sino que además -y al mismo tiempo- refieren a la percepción del peso relativo que la ciudad recibe o disputa dentro de equilibrios espaciales extensos e históricos, ya no (únicamente) por oposición sino también por relación coexistente (de continuidad, dependencia, dominación, conexión o tensión) entre lugares que forman parte de ese conjunto amplio y que le brindan sentido a la propia posición. Me interesa poner en diálogo esas coexistencias con el tema de la convocatoria de este dossier, atendiendo a los aspectos regionalizados y regionalizantes que ellas presentan.

El trabajo se estructura en tres acápites que analizan las figuras de coexistencia espacial mencionadas, precedidas por unas breves notas que contextualizan el estudio. Al final, se ensayan unas conclusiones.

\section{Televisión digital en la capital provincial: notas preliminares}

San Salvador de Jujuy es la ciudad capital de una provincia de frontera del Noroeste Argentino ubicada en la región surandina, a mil seiscientos kilómetros de la capital nacional (Buenos Aires). Su condición liminar permite pensar el poder y la cultura desde una posición "excéntrica" a la tradición dominante de los estudios sobre ciudades latinoamericanos, y potenciar la capacidad crítica del teorizar de los Estudios Culturales (Hall y Mellino 2011:30). La articulación de varias escalas en el espacio urbano de la capital jujeña -entre las que podemos mencionar la relación de exclusión del proyecto nacional asociada a la implementación de políticas neoliberales que Manzanal (1999) describe como desarticulación profunda; las características de ser la capital de una provincia de frontera que recibe un flujo permanente (aunque fluctuante) de migrantes bolivianos y bolivianas (Sala, 2005); la dinámica excluyente con el conjunto provincial que Karasik (ms) describe como un proceso histórico de drenaje de la población de las tierras altas hacia las áreas de desarrollo capitalista más dinámicos; la profunda desigualdad social que se verifica en el territorio urbano (García Vargas 2009); la fuerte exposición a las dinámicas culturales globales vinculadas al turismo a partir de la declaración de la Quebrada de Humahuaca como Patrimonio de la Humanidad por UNESCO en 2003 (Troncoso 2009); la mayor cantidad porcentual de hogares de hogares de todo el país en los que algún o alguna integrante se reconoce 
García Vargas. La puerta de Latinoamérica (desde las rutas Argentinas): San Salvador de Jujuy en geografías...

como indígena o descendiente de indígenas (de acuerdo al Censo 2010)- la vuelve un sitio especialmente fértil para el análisis cultural ya que esta serie de superposiciones de experiencias espacio-temporales en situación de frontera multiplica la intensidad e historicidad de su desigualdad social y su heterogeneidad humana y, por lo tanto, de las disputas hegemónicas para representarla en clave de interculturalidad (Briones 2008; Caggiano 2005), diversidad (Grimson y Karasik, 2017; Rabey y Jerez, 2000) o discrepancias (Carman, 2006; Massey, 2005a; Segura, 2015).

El período durante el cual se produjeron o difundieron los programas televisivos seleccionados (2011-2013), se realizó el trabajo de campo (2011-2016) y la tarea analítica (2011-2016) asocia la riqueza de esta liminaridad excéntrica de San Salvador de Jujuy a dos condiciones contextuales relevantes, vinculadas a transformaciones de la televisión, y a la decisión de trabajar con estas narrativas en un momento en el que la televisión se apaga mientras se encienden otras pantallas.

En primer lugar, aún en una ecología de medios caracterizada por la transmedialidad y la convergencia, la I Encuesta Nacional de Tecnologías de la Información y la Comunicación (ENTIC) señala que en 2011 la televisión era la tecnología de la información y la comunicación más presente en los hogares urbanos de Argentina, en todas las regiones y en todos los niveles de ingreso. En el caso específico de Jujuy, el relevamiento indica que el $94.9 \%$ de los hogares poseía televisor, y el porcentaje se eleva a 96,9\% para el aglomerado San Salvador de Jujuy-Palpalá.

En ese sentido, es importante notar que en la idea del "fin de la televisión" (Gilder, 1992; Negroponte, 1995), e incluso en la de su mutación vinculada a las transformaciones en las experiencias interactivas de las audiencias (Islas, 2010; Scolari, 2008) suele generalizarse las prácticas ligadas a los usos de la audivisualidad ${ }^{3}$ y la audiovisualización ${ }^{4}$ de los y las analistas -0 , al menos, los de quienes habitan áreas urbanas y acceden a formas de conexión fluidas- al conjunto de la sociedad y las regiones geográficas, y de ese modo se invisibiliza ${ }^{5}$ la heterogeneidad y desigualdad de esas prácticas y-quizá sobre todo- la distancia entre las situaciones desiguales en los momentos de producción y de reconocimiento de narrativas audiovisuales. De ese modo se niega, por un lado, la pregnancia de los medios tradicionales; luego, la importancia determinante de las tecnologías vinculadas a la conexión entre los dispositivos digitales y las redes de telefonía o distribución de flujos de contenidos en ese tránsito sociotécnico; y, finalmente, la inequidad en el acceso a los circuitos que aseguran la distribución amplia de esos contenidos y en el emplazamiento de las empresas que

\footnotetext{
3 Denomino "audiovisualidad" a la relación con las prácticas de producción y uso de la audiovisualización, al conjunto de competencias necesarias para producirla y comprenderla en una comunidad determinada. Audiovisualidad designa "eso" que hacemos con la audiovisualización.

4 Se utiliza "audiovisualización" para hacer referencia al uso de determinadas imágenes, palabras, sonidos y estrategias de montaje (y no otros) que permiten mostrar/ver en un específico material determinados temas, actores/actrices sociales, espacios, tiempos y/o relaciones entre ellos) (e inaudiovisualización a la ausencia de imágenes, sonidos y montajes sobre determinados temas, actores/actrices sociales, espacios, tiempos y/o relaciones en esos u otros materiales).

5 Se denomina "visibilización" al proceso social de poner en agenda y/o debate público determinados temas, espacios, actores/actrices sociales, relaciones, etc. (e invisibilización, al proceso de no hacerlo).
} 
los alojan. Esto es, la problemática del acceso material a las tecnologías se inscribe en mapas históricos de desigualdades nacionales y regionales y también en aquellos que se trazan diariamente en la lucha y resistencia contra ellas.

En segundo lugar, ese proceso de multiplicación y transformación (desigual) de las pantallas y de los públicos convive con la inminencia del apagón analógico de la televisión (previsto para 2019 en Argentina). Durante el trabajo de campo, esas variaciones se sobrepusieron con el período de transformación normativa y organizativa de los medios operada por la conjunción de la sanción de la Ley 26522 de Servicios de Comunicación Audiovisual (LSCA), el decreto 1148/09 regulatorio de la Televisión Digital Abierta (TDA) y las modalidades de implementación de ambos, asociados a numerosas políticas públicas.

Tres de los programas analizados en este trabajo han sido financiados por fondos públicos destinados a la promoción de contenidos federales, y los cuatro inscriben su proceso productivo en la consideración del tiempo que va desde el anuncio y posterior sanción de la LSCA (en octubre de 2009) hasta las sustanciales modificaciones a esa norma que introdujeron los decretos 13, 236 y 267 en diciembre de 2015, completados luego con otros decretos durante todo el año 2016, hasta el desmantelamiento del sistema de Televisión Digital Abierta en enero de 2018.

Durante el período de realización y emisión de los programas analizados (2011-2013), las políticas de fomento de la producción asociadas a la Ley de Servicios de Comunicación Audiovisual (LSCA) interpelaron las prácticas sedimentadas de la comunidad audiovisual local, tanto en términos de las condiciones generales de posibilidades de producción como en la reflexión sobre los contenidos producidos y su relación con los que circulan habitualmente en las pantallas televisivas. Esas interpelaciones se dieron en un marco también cambiante y crecientemente visibilizado sobre la definición, percepción y valoración estatales del lugar de los medios y los servicios de comunicación audiovisual (especialmente, la televisión) en relación con "la cultura nacional" abiertamente politizado. Al mismo tiempo, esas mismas preocupaciones implicaron la generación de políticas de asistencia para acompañar la migración al entorno digital de la televisión por aire analógica y el visionado de la TDA en parte de las audiencias (aquella considerada como "población prioritaria").

Todas estas consideraciones sostienen la decisión de indagar los vínculos entre narrativas audiovisuales, configuraciones culturales y producción social del espacio urbano a partir de un corpus que combina el análisis de sentidos de ciudad de programas televisivos producidos localmente y el de entrevistas a sus realizadores y realizadora.

\section{La puerta de Latinoamérica: ser ciudad entre dos mundos}

Para mí [San Salvador de Jujuy] es la puerta de Latinoamérica. Así... "re", digamos... Salta es el último orgullo argentino criollo (yo me imagino al caballo blanco con el poncho rojo) y acá ya es el mercado, las naranjas y la doña en la calle. Y 
García Vargas. La puerta de Latinoamérica (desde las rutas Argentinas): San Salvador de Jujuy en geografías...

el mercado... ese caos que para mí es alucinante ( $\mathrm{PaK}$, mi énfasis y sus comillas - expresadas gestualmente- en el "re")

Si vivir es "pasar de un lugar a otro intentando no golpearnos" (Perec, citado por Segura 2015: 19), ¿qué implica poder asomarnos, desde la puerta de San Salvador de Jujuy, a Latinoamérica?

En la imagen de la puerta hay un juego de oposiciones y mediaciones que expresa el perfil fronterizo del territorio jujeño, en su doble carácter de límite y contacto. Cuando una puerta se abre, permite pasar de un espacio a otro, cuando se cierra, lo impide. Alrededor de los mundos que esta ciudad-puerta intermedia se ubican conjuntos específicos e identificables de elementos, ordenados en parte mediante el "pareo" con otras ciudades y con el mundo andino, pero que al mismo tiempo permiten advertir la participación en mapas extensos y la búsqueda de características definitorias combinadas con el peso relativo de San Salvador de Jujuy en cada uno de esos conjuntos mayores y "entre" ellos.

$\mathrm{Si}$ "los lugares son contextos constituidos por tránsitos y traducciones, que siempre se definen por sus relaciones con otros lugares" (Grossberg, 2012: 52), los espacios que esta específica "puerta" intermedia son claramente Argentina y Latinoamérica. Ni uno ni otro término de referencia espacial son inequívocos y se construyen por relación con conjuntos específicos de elementos, rasgos y lugares. La Argentina invocada es criolla, específicamente, la capital jujeña se opone al "último orgullo argentino criollo" (Salta) y participa, en cambio, del "caos alucinante" de un mapa mayor (Latinoamérica). ${ }^{6}$

En primer lugar, la imagen revela que, para quien está en Argentina, Latinoamérica queda del otro lado de la puerta, queda "allá", queda afuera. Y San Salvador de Jujuy es el umbral de salida hacia ese espacio. ${ }^{7}$

En los sentidos de ciudad de la productora de Murmullo, la tradición a la que se refiere el territorio nacional extenso al que se opone San Salvador de Jujuy resulta vinculada al orden, mientras que la geografía amplia subcontinental guarda relación con el vínculo que establece Sarlo (1999) entre la ciudad y la "modernidad periférica" mediante el concepto de "cultura de mezcla" como característica latinoamericana de la experiencia urbana ${ }^{8}$, categoría que -en conjunto con otras, tales como "culturas híbridas" (García Canclini, 1990), "transculturación” (Rama, 2008), "formación social abigarrada" (Zavaleta Mercado, en Antezana 2009), o "sectores ch'ixi” (Rivera Cusicanqui, 2010) - propone abordar las mixturas producidas por y productoras de la vida urbana en el subcontinente a inicios del siglo XX.

Para expresarlo brevemente, y no sin riesgos, recurro a una cita del análisis de Luis Antezana (2009) sobre la obra de Zavaleta Mercado con la que intento una aproximación al zócalo común que encuentro en esta serie de conceptos que se actualizan

6 Espacio al que sin embargo pertenece incipientemente: es la puerta, no es el corazón ni la sala.

7 En la historia de las migraciones populares bolivianas a Argentina, a su vez, resulta el umbral de entrada (Caggiano, 2005).

${ }^{8}$ Concretamente, la autora ofrece ese término para referirse al área metropolitana de Buenos Aires en el entresiglo XIX-XX. 
en el "caos alucinante" con el que esta realizadora resume su percepción de la ciudad en relación con Latinoamérica: "consiste en desplazar las tradicionales reflexiones centradas en el problema de 'lo hegemónico en (y sobre) la diversidad' hacia una percepción de 'la hegemonía de la diversidad'. Quizá lo múltiple tiene su(s) manera(s) de ser... en diversidad" (Antezana, 2009: 119, entrecomillado y resaltado del autor).

Ese conjunto de categorías, si bien diversas, se recortan contrastivamente sobre el de "aculturación", como noción de dicotomía con posición dominante para la interpretación de las "ciudades masivas" en otros estantes de la biblioteca latinoamericana (por ejemplo, Romero, 2001). Además, una parte importante de esos conceptos brinda atención a la producción cultural industrial como clave de bóveda del entresijo urbano latinoamericano (la localización urbana de las industrias culturales cfr. Aguilar, 1999; Paiva y Sodré, 2004; Jaguaribe, 2016).

Por supuesto que una mezcla o combinación de elementos no es necesariamente caótica, pero sí lo es aquella que se esgrime para caracterizar esta ciudad en este caso. La referencia, complementaria en la actividad de "pareo" para brindar sentido a San Salvador de Jujuy, es también una ciudad: la capital política y administrativa de Bolivia. Por último, el caos no es necesariamente negativo y aquí se invoca, justamente, en su carácter abigarrada e inspiradoramente creativo.

El espacio de intermediación ocupado por la ciudad es interpretado a partir de la intersección de relaciones étnicas y nacionales, por un lado, y a un conjunto de tematizaciones de lo urbano, por el otro. ${ }^{9}$ En términos de conexiones de la ciudad con espacios amplios, la Argentina se vincula a la tradición gaucha salteña pero también al orden y la planificación urbanas de una ciudad intermedia de la pampa húmeda -como Rafaela-, mientras que San Salvador de Jujuy participa del carácter "latinoamericano" de "la doña vendiendo naranjas en la calle" y la apropiación general de la calle y el mercado por parte de los sectores populares como en la capital política de Bolivia -una "versión pequeña" de La Paz.

Ahora bien, conjuntos parecidos de elementos son los que el director de El viaje señala como puntos de interés para el turismo:

el turista lo primero que viene a ver aparte de su historia, por lo que pasó en la Guerra de la Independencia, es poder visitar estas ferias en las que encontrás artículos de diferentes partes y de lo andino (JoV)

Sin embargo, en este caso la serie vinculada a la Guerra de la Independencia articula con mayor fortaleza a la ciudad con Argentina, a través de una de las argumentaciones principales del discurso hegemónico local que alude a ese hecho histórico como fuente de diversos reclamos que fundamentan la pertenencia nacional (Burgos y García Vargas, 2008). Esa ciudad mostrada al turismo es la mezcla de un pasado

\footnotetext{
9 La productora de Murmullo alude específicamente a su formación universitaria, y en ella la lectura de la idea de espacio intermedio o in-between de Bhabha cuando comenta el efecto que le produjo conocer la ciudad de San Salvador de Jujuy.
} 
heroico que vincula este espacio con el marco nacional, y unos espacios paradigmáticos de esa mezcla con artículos "de diferentes partes y de lo andino". La ciudad es mezcla e intersección entre esas escalas espaciales, pero no se ubica exclusivamente en el tipo de articulación fronteriza señalada por "la puerta". En un mapa turístico, este sentido de ciudad reúne raíces (argentinas) y rutas (argentinas y andinas) para identificarse en el conjunto nacional y en el latinoamericano.

\section{El hecho de la periferia: ser ciudad en los márgenes}

[En el NOA] hay muchas problemáticas en común. La postergación básicamente, o sea, hay muchas problemáticas postergadas y en gran parte postergadas por esto, porque no son visibilizadas (...) O sea, el hecho de la periferia, de estar muy alejados (DiR)

En el marco de geografias extensas y desiguales, las ciudades adquieren una relativa autonomía cuyo alcance cambia de acuerdo a las relaciones que establezcan con centros y periferias que también varían. Como sostienen Agüero y García (2010), "estas geografías constituyen equilibrios provisorios que pueden modificarse en la larga o mediana duración" (25).

La asistente de producción de Murmullo habla de producir "desde el lugar de origen" [cuando no es el centro] o, directamente, "desde un lugar que no es el centro". Así, alude a un mapa de flujos desiguales vinculados al desarrollo nacional de las industrias culturales, y solapa el espacio social de la televisión al marco general de la producción social del espacio. En términos de condiciones productivas, el primer marco espacial para interpretar la inequidad del desarrollo capitalista de las industrias culturales es nacional. Esto es, para estos productores y productora audiovisuales el capital es mucho más móvil que el trabajo, pero al mismo tiempo se concentra en una ciudad precisa (Buenos Aires), y eventualmente alcanza ciudades de mayor desarrollo que San Salvador de Jujuy. Los problemas regionales son experimentados por estos productores y productoras, como consecuencia de una estructuración histórica desigual(ada) de la producción audiovisual en el marco nacional, pero también como una dimensión que atraviesa el conjunto de la vida social regionalizada de quienes habitan esta específica ciudad (Massey, 1994).

Si bien ambas posiciones relativas (lejanía o marginalidad) no son idénticas, ya que una alude a la distancia respecto de un punto y otra al efecto de concentración de recursos y poder en un centro que le presta superioridad sobre la periferia, tienen en común que -en el contexto espacial amplio de la nación- a veces se construyen de manera solitaria o, en otros casos, se comparten con otras ciudades y se expanden hasta abarcar la situación de quienes producen audiovisual en la región conformada por las provincias del Noroeste argentino, del Norte Grande (NOA y NEA), o bien del conjunto completo de las provincias. 
En la cita inicial de este apartado, el director de Murmullo piensa la región NOA como "lejana", "postergada" y al mismo tiempo como intersección de relaciones que se dan tanto al interior como fuera de la región misma. La denuncia de la "postergación" -frecuente tanto en el contrapunto Buenos Aires-provincias del pensamiento crítico argentino (Grimson y Caggiano, 2015), como en los discursos mediáticos (García Vargas, 2006), cotidianos (Burgos, 2014; Gaona, 2015) y político-partidarios locales (García Vargas, 2009; Romero, 2010)- permea tanto la demanda de visibilizar los temas o las historias "autorreferentes" (que están "acalladas") para superarla, como la percepción del propio lugar de producción audiovisual como "lejano" y "periférico" ("estar tan lejos", en las palabras del director de El viaje) en relación con los principales centros de producción y capacitación.

Mencionamos ya la idea de "modernidad periférica" acuñada por Beatriz Sarlo para dar cuenta de la cultura de mezcla urbana característica de la Buenos Aires de las vanguardias de las décadas de 1920 y 1930. En relación con ese sitio, San Salvador de Jujuy es doblemente excéntrica: no solamente es latinoamericana, sino que además no es la capital nacional. Históricamente, esto valió una interpretación extendida para las ciudades provinciales como marginales en Latinoamérica, que también intersecta con la modernidad reservando para ellas la relación con el estancamiento. José Luis Romero (2001) indica, al referirse a las "ciudades estancadas" (por oposición a las industrializadas y para el período que va de 1880-1930):

Conservaron su ambiente provinciano las ciudades que quedaron al margen de la modernización. No cambiaron cuando otras cambiaban, y esa circunstancia les prestó el aire de ciudades estancadas. Muchas de ellas lograron, sin embargo, mantener el ritmo de su actividad mercantil al menos dentro de su área de influencia, pero mantuvieron también su estilo de vida tradicional sin que se acelerara su ritmo (...) Ciertamente el horizonte que ofrecían no se ensanchó, cuando en otras ciudades parecía crecer la posibilidad de la aventura, de la fortuna fácil y el ascenso social (...) Fue intenso el sentimiento que provocó el contraste, y muchos lo expresaron como testimonio de una situación contradictoria (257-258)

Esa histórica relación entre periferia, marginalidad y "estancamiento" se actualiza en la percepción del director de El viaje:

(A)1 terminar la facultad me vine a Jujuy como para querer abrir un poco estas posibilidades de producir audiovisual. Al principio era el cine y todo rondaba alrededor de eso pero acá en Jujuy la distancia fue como determinante en la profesión, y también la presencia en Córdoba donde la parte audiovisual quizás está un poco más desarrollada, y bueno, acá fue una lucha comenzar de cero. (JoV, director de El viaje) 
Es decir que las distancias se establecen en términos nacionales, pero el contraste se ve posibilitado por la experiencia de (y en) otra ciudad. En el programa Jujuy Profundo, el conductor señala:

Otras provincias nos sacan ventaja, se las critica porque son excesivamente chauvinistas, nosotros parece que pertenecemos a otro territorio, que somos algo aparte de la Argentina (Jujuy Profundo, emisión 3, temporada 5).

El espacio en el que ubica a Jujuy este productor no se restringe al NOA (aunque lo contiene parcialmente) y encuentra la clave de la regionalización en un "pasado histórico común". Ese pasado se vincula específicamente a la historia independentista, por lo que menciona a la región como un "teatro de operaciones" abarcativo del Alto Perú, la República Plurinacional de Bolivia y el NOA. En relación con aquel espacio histórico, Jujuy resulta central ya que, para el realizador de Jujuy profundo, el trayecto vital de la nación Argentina "se parió en esta tierra".

Siempre hay versiones encontradas pero la única verdad, la única realidad como yo digo cuando termino el programa, [es que] en Jujuy nació la Patria. Que esta patria, esta República Argentina se parió en el norte argentino. $(\mathrm{FeC})$

Esa centralidad perdida, vinculada al origen y posibilitadora de la existencia de la nación, se activa en el vínculo actual con otros sitios, entre los que Buenos Aires se percibe como un "otro abusivo" en lo simbólico al narrar la historia silenciando la heroicidad de Jujuy, central para la constitución de la nación.

El conflicto, entonces, es extra-regional y se entabla con quienes se arrogan el poder de enunciación (y de audiovisualización) sobre la verdad histórica (localizados, para el periodista, en Buenos Aires). Ese conflicto se nombra como (ausencia de) federalismo.

En ese entonces el territorio no era marginal, era el centro... no fue la independencia de la Argentina, fue la independencia de la Patria Grande, de las Provincias Unidas de Sudamérica (...) La historia la escriben los pueblos, y la escriben con sangre. Aquí la historia de Argentina está escrita con un sabor porteño, y con tinta y no con sangre. Creo que los jujeños tenemos que escribir la historia. (Jujuy profundo, emisión 3, temporada 5, ver link).

La centralidad de la región surandina para el proceso que llevó a la formación del estado nacional juega en contrapunto con el lugar relativo en el momento previo a la configuración espacial nacional.

En términos del "espacio social de la TV", Jujuy Profundo asume como contenidos centrales la confrontación con la estructuración del proyecto nacional en la economía simbólica de la nación. Su realizador, además, es el único que piensa la "región audiovisual" en término de audiencias y no de interrelaciones entre productores 
y productoras o de historias en común (situación que invoca indirectamente a las audiencias pero que se asienta en la percepción o construcción de narrativas sobre una experiencia social compartida entre realizadores/as). El realizador de Jujuy Profundo indica que no cree que su programa resulte de interés fuera de la provincia, y señala que las historias de Jujuy se vinculan con las de Salta, pero que si emitiera su programa en esa provincia no llegaría al público general y de todas las generaciones que tiene en Jujuy, sólo a profesionales de la historia. Jujuy Profundo se piensa y se hace en la dinámica productiva tendiente a constituir la grilla de programación de la señal local del servicio de televisión por vínculo físico, no dialoga con otros productores y productoras, ni problematiza las transformaciones (ni disputa los recursos) de las políticas de fomento amparadas en el art. 153 de la LSCA vigente en ese momento.

\section{Una cuestión de cercanía: un espacio amplio y común en los márgenes de la nación}

Los concursos de las convocatorias federales (INCAA, 2010 y 2011) promovieron, en sus bases, la inclusión de la diversidad y heterogeneidad constitutivas de nuestro país, y al mismo tiempo organizaron esa diversidad en regiones que se agruparon por "proximidad geográfica, histórica, social y cultural" (INCAA, 2010 y 2011). La base para la constitución de regiones, a su vez, fue provincial. En los objetivos, la convocatoria indica "fomentar la producción de contenidos en todo el territorio nacional a fin de promover la diversidad cultural de sus diferentes regiones" (INCAA, 2010, mi énfasis) y "desarrollar las capacidades profesionales de directores, productores y guionistas independientes de cada una de las provincias del país" (INCAA, 2010, mi énfasis). En ambos casos, para "contribuir a la formación de un acervo de contenidos para la televisión digital” (INCAA, 2010, mi énfasis).

En la convocatoria la nación audiovisual busca ser una, aun siendo múltiple. Se habla de un acervo de contenidos. Esto es, un archivo, un capital audiovisual que se deposita en un Banco, el BACUA (Banco Argentino de Contenidos Universales Audiovisuales). La multiplicidad, a su vez, se regula en términos regionales, regiones que se constituyen en el agrupamiento de provincias.

Las convocatorias por concursos de INCAA se realizaron con el objetivo específico de federalizar la producción audiovisual para el SATVD-t, enfrentando de ese modo la concentración geográfica de la producción audiovisual argentina en Buenos Aires, mediante el mapeo del país en seis regiones que recibieron subsidios por montos idénticos para la realización televisiva de diversos formatos. 


\section{Regiones de la convocatoria de concursos federales INCAA}

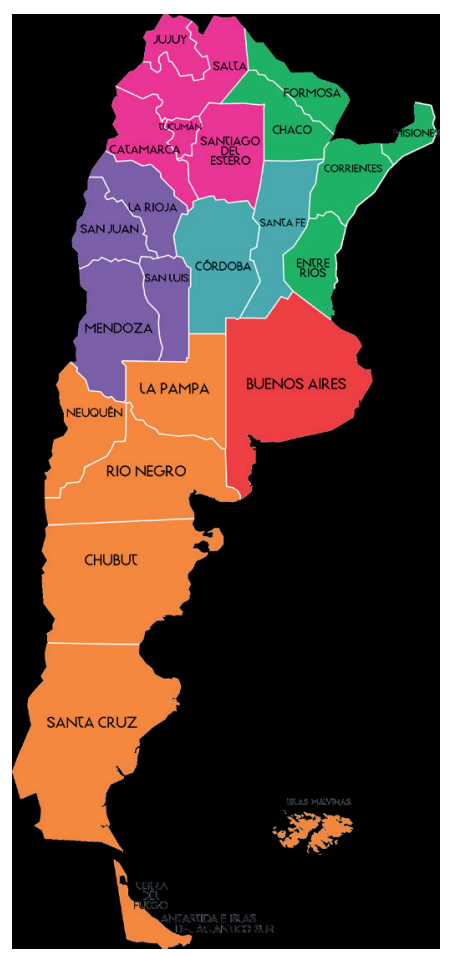

Fuente: elaboración propia sobre convocatoria INCAA (2010).

Como he sostenido en otro lado (García Vargas, 2014), el mapa colorido de las regiones INCAA puede pensarse como una "renovación situada" de la dinámica productiva histórica en las provincias por la variedad de géneros (entre los que se incluye el documental), por el destino (la convocatoria es para televisión), y por la concepción de distribución de recursos (que los organiza con perspectiva federal, otorgando idéntica cantidad de fondos a cada una de las regiones del país).

La tarea de articular la convocatoria en regiones dialoga, y al mismo tiempo potencia, algunas de las formas previas de organización ya iniciadas desde la conformación de numerosas redes de producción independiente y alternativa, para atender a los desafíos de su desarrollo o visibilización (García Vargas, 2015).

Los temas, problemáticas e historias que vinculan potencial o activamente los contenidos producidos en la esfera regional se mencionan en la convocatoria pero ese juego entre nación, provincias y región también está presente en la interpretación de la propia posición (marginalmente desventajosa y desaventajada) por parte de la y los productores. Por su parte, la mención a historias o rasgos culturales e históricos comunes asume diversas formas entre ellos. 
En ocasiones, se relaciona a la postergación. En ese caso, la región reúne las posibilidades narrativas "autorreferentes" a partir de esa posición desventajosa:

hay una necesidad de (..) contar historias que sean autorreferentes en la región que eso nos aúna en la región, que tiene que ver con esto, con éstas temáticas postergadas (DiR)

Entre estos realizadores y realizadora, el pensamiento en torno al propio lugar nacional desde la común pertenencia a una escala noroestina, se construye a partir de prácticas laborales y productivas que incluyen la inserción en redes y colectivos localizados (en términos de circulación de recursos y oportunidades de formación y de trabajo) y, en un único caso, en la consideración de potenciales audiencias. ${ }^{10}$

No es menor que, al mismo tiempo, las convocatorias de INCAA que dieron origen a las series Maestros y El viaje y al unitario documental Murmullo se estructuraran en base a regiones nacionales constituidas por agrupamientos provinciales. En ese sentido, la convocatoria recupera, potenciándolas, tanto ordenamientos administrativos estatales nacionales como algunas de las formas previas de organización iniciadas desde la conformación de numerosas redes de producción independiente y alternativa, para atender a los desafíos de su desarrollo o visibilización. Las lógicas de articulación de esas redes, si bien variadas, son en general sensibles a la territorialidad, y de base local o regional.

nosotros tenemos una articulación regional a través de la Red Andina de Video que fue una formación que la hicimos primero a nivel provincial en el año 2004 y después más tardíamente pudimos enlazarnos con otros compañeros de Salta, Tucumán, Santiago, Catamarca y La Rioja y planteando de alguna manera cuestiones que tenían que ver con esto de poder trabajar colectivamente, de romper las fronteras [provinciales], de poder producir de manera regional $(\mathrm{ArO})$

La importancia de la localización en el pensamiento audiovisualista independiente se evidencia en que eligen mayoritariamente la designación por la localidad o la provincia para sus eventos y formas asociativas, por ejemplo: Oberá en cortos, Jujuy cortos, Santiago del Video (para el caso de encuentros), o bien Asociación de Realizadores Audiovisuales de Salta (ARAS), Espacio Norte Audiovisual o Red Andina de Video (en términos de agrupaciones). La Red Andina de Video que se menciona en la cita precedente es una experiencia organizativa de productores independientes para incidir en las formas de distribución de recursos provenientes de políticas de fomento en las provincias de Jujuy, Salta, Tucumán, Santiago del Estero, Catamarca y La Rioja, entre otros objetivos; mientras que Espacio Norte Audiovisual incluye realizadores y realizadoras de las provincias del NOA y el NEA con fines similares. En ambas redes, el colectivo de comunicación que

${ }^{10}$ El juego de espejos entre presencias y ausencias de las audiencias y los públicos en los discursos de realizadores y realizadoras (y viceversa) constituye un tema en sí mismo, vinculado al reconocimiento de situaciones propias y de lxs otrxs en la construcción de sentidos de ciudad (mediatizada) que se explora en otro trabajo (García Vargas, 2017). 
García Vargas. La puerta de Latinoamérica (desde las rutas Argentinas): San Salvador de Jujuy en geografías...

integra este realizador tiene presencia fundadora y relevante desde una oposición que califica de "militante". Esas modalidades de articulación regional se potenciaron en el debate de las políticas asociadas a la LSCA y la TDA. ${ }^{11}$

Pero la convocatoria también opera con un efecto regionalizante entre quienes no pertenecen a esa tradición (que podría calificarse como popular "en sentido fuerte", cfr. Alabarces), reuniendo espacialmente experiencias productivas a partir de la interpelación del Instituto:

En ese momento [se refiere a la primera convocatoria federal para televisión de INCAA, en 2010] no existían vínculos, había dos o tres productoras emergentes en Jujuy. Salta tiene otro capital AV, muchísimo más grande que el nuestro. Y Tucumán también está poco desarrollada. Creo que después de eso hubo una región audiovisual, se crearon vínculos con gente de Salta y Tucumán, y al año siguiente se sumó Catamarca. (JoV)

Para el director de El viaje, la región se "armó" a partir de la interpelación producida por las políticas de fomento. Tanto entre quienes observan el carácter regionalizante de la convocatoria como entre quienes se organizaron regionalmente mucho antes de la sanción de la ley (y la perciben como institucionalización de prácticas y de sus propias propuestas previas), la posibilidad de pensar la relación con el mapa nacional desde la escala regional se esgrime como reclamo pero también como posibilidad articulatoria de demandas que fortalece la propia posición local al compartirla colectivamente desde el NOA.

La persistencia en las preocupaciones sobre el lugar relativo compartido, ya sea que se interprete como reconocimiento de ese lugar por las convocatorias INCAA o como emergencia de una escala productiva alumbrada por la organización territorial de sus políticas de fomento, muestran en qué medida una región es cultural, histórica, administrativa, y se construye socialmente. También permite observar que la regionalización tiene efectos concretos en la discusión sobre los derechos y las condiciones de ejercicio de la "ciudadanía audiovisual" nacional al momento del trabajo de campo. Como indica Jelin:

Las regiones se definen en un doble movimiento: como partes de un todo mayor, y como áreas o zonas relativamente amplias, más amplias que 'lo local'. En el marco de la historia mundial de los últimos tres siglos, las regiones se fueron definiendo en relación a una unidad administrativa moderna: el Estado-nación. Cuando se toma al Estado-nación como ese 'todo mayor', las

\footnotetext{
${ }^{11}$ Es interesante observar cómo, en el contexto actual, las redes nacionales (por ejemplo, DOCA, la asociación de Documentalistas Argentinos que se conformó en 2001, durante el apogeo de la crisis del gobierno de la Alianza), ya existentes en el momento del trabajo de campo, vuelven a ser centrales en la confrontación, (por ejemplo, convocando y articulando la demanda frente a la intervención de INCAA), mientras que las regionales siguen firmando los documentos como apoyo a esa configuración articulada nacionalmente.
} 
regiones son los espacios territoriales contiguos que, por motivos puramente administrativos o como reflejo de alguna característica económica, cultural, social o geográfica (o la combinación de más de una), son definidos como unidades menores dentro del Estadonación (Jelin, 1999, en Caggiano 2005: 122).

En este caso, esa construcción social de la región se realiza en una coyuntura de transformación de la dinámica productiva que se presenta como superadora de la concentración geográfica. Por otra parte, las regiones dialogan entre sí y con la ciudad de Buenos Aires que ocupa la posición "central". La condición periférica que emerge continuamente en las entrevistas alude a los paisajes mediáticos (Appadurai, 2001) casi literalmente, ya que refiere al flujo y las imágenes de la televisión en Argentina. Como ya se ha indicado, Gonzalo Aguilar (1999: 264) señala que la televisión en Argentina fue desde el inicio "un factor fundamental de unidad territorial que reafirmaba (...) el poder de Buenos Aires", ya que al recibir idénticas imágenes y mensajes los hogares del territorio nacional se sentían "más integrados en el imaginario nacional y colectivo". Al mismo tiempo, la televisión transformó la idea de territorio, modificando la percepción de las distancias. Se trató de un impulso integrador, pero también homogeneizante y asimétrico.

En ese paisaje mediático nacional desigual(ado), cuando se queda "lejos" es operativo fortalecerse con quienes están "cerca" :

(...) el concepto básicamente es y por ahí tiene que ver un poco con la cercanía. Nosotros... es más fácil vincularse con un compañero que está en Salta o en Tucumán que con uno que está en Neuquén o la Patagonia. Aun cuando las problemáticas puedan ser similares o podamos tener puntos en contacto. De hecho por ejemplo gran parte de las demandas y las luchas que venimos planteando, en estos últimos años hicimos una fuerte alianza con el NEA también (...): cuestiones de capacitación, cuestiones de achicar la brecha tecnológica, por otro lado, que... digamos que hay una exigencia del mercado que cada vez te pide mayor calidad pero acceder a tecnología que te da esa calidad no es tan sencilla de conseguirla o somos pocos los que las tenemos. (ArO)

La construcción social de la región entre realizadora y realizadores alternativos e independientes, aún en su heterogeneidad, indica en qué medida las políticas de fomento tuvieron trascendencia política y social. El guionista de El viaje resalta que las convocatorias son regionalizantes, pues interpelan en este sentido, y destaca que ese le parece un acierto en términos posibilitadores de proyectos en común, redes y organización del trabajo. Reconoce vínculos regionales en la dinámica general de la población, e indica las migraciones interregionales como aspecto saliente del NOA. Esto es, alude a un contexto referencial compartido. Pero al mismo tiempo, para el caso específico de la dinámica y los trayectos de audiovisualistas en el NOA, el mismo 
guionista indica que Jujuy “mira más a Salta que a Tucumán”, situación que le sorprende por el peso relativo de Tucumán en términos de desarrollo de experiencias "privadas" de realización televisiva.

El creador, productor y conductor de "Jujuy profundo", en cambio, piensa en un espacio regional diferente, vinculándolo a la variación del lugar relativo de la provincia en términos de centro y periferia en dimensión histórica (concretamente, su papel en las guerras de la independencia) y a las audiencias.

\section{La ciudad como punto de un camino: relaciones profesionales con acento}

Llegué a Jujuy en enero de 2007 con la intención de hacer una experiencia distinta, aprender a filmar desde un lugar distinto $y$ distante al "centro" del país (Buenos Aires). Me parecía un verdadero desafío poder estar en un rodaje, producir y contar historias locales en el marco de un grupo con un perfil en comunicación popular, que trascendiera lo meramente cinematográfico (es decir, lo técnico). Una antropología audiovisual si se quiere... (PuK)

Las formas del movimiento, tan presentes en tres de las cuatro producciones analizadas para pensar la ciudad (entre el interior y el exterior de la misma ciudad, y al interior de su propia cartografía urbana), son también una constante en las biografías y trayectos profesionales de las y los realizadores. En ellos, se verifica un tipo de movimiento habitual en las clases medias locales vinculado fundamentalmente a los procesos formativos (a la obtención y acumulación de recursos educativos).

En ese sentido, la puerta, como metáfora de la posición de frontera de la ciudad, también alude al trayecto previo de la propia realizadora, que "entra" a Latinoamérica desde San Salvador de Jujuy y al sumarse a un colectivo de comunicación popular local en un trayecto profesional y biográfico que se inicia en Rafaela, una ciudad intermedia de la provincia de Santa Fe. Ese trayecto que ubica a San Salvador de Jujuy como espacio de trabajo en una red compleja de conexiones que informa la biografía profesional de esta realizadora es similar a los de los demás productores, con la única excepción del referente de Jujuy Profundo.

Sin embargo, que esta ciudad haya sido elegida como lugar de capacitación es excepcional en este conjunto, y corresponde a la biografía profesional de la entrevistada más joven del conjunto, quien además se considera parte de una "generación federal" (García Vargas, 2015). ${ }^{12}$ En los demás casos, el trayecto formativo es el inverso: se relaciona con otras ciudades que operan como centros formativos, y se regresa o se llega a San Salvador de Jujuy (una ciudad "lejana" y periférica") una vez concluido ese ciclo. Se trata de una ubicación relativa vinculada a las rutas argentinas, ya que los caminos

${ }^{12}$ Tal categoría emerge de entrevistas y alude a la homología generacional de quienes se incorporaron al mundo del trabajo audiovisual durante el período de vigencia de las políticas de fomento asociadas a la LSCA (García Vargas, 2017). 
formativos y profesionales relevados se realizan en constantes desplazamientos desde o hacia otros puntos del país, principalmente urbanos, como Salta, Tucumán, Córdoba, Rafaela, Buenos Aires, Neuquén. En ocasiones, también incluye otras localizaciones de la provincia (Tilcara) o del mundo (Cannes, Sevilla, Málaga, Caracas).

En el caso del tránsito al interior de la región, esas experiencias de las clases medias forman parte de un contexto mayor de intercambio permanente:

En relación con las continuidades [regionales del NOA], me parece que se dan en términos de problemáticas sociales, culturales, económicas, etc. La migración regional es un hecho que integra al NOA (FeB).

Rita Laura Segato (2007) cita a Naficy (1999) para hablar de un "cine con acento" que se da aún en directores exiliados, y complejiza la escala nacional para dar cuenta de dinámicas de frontera entre Argentina y Brasil. La autora se refiere a marcos nacionales (como escalas casi excepcionales en el proceso general de mundialización y concentración de la producción cultural) y se ocupa del cine, pero deseo recuperar su apreciación advirtiendo que la adapto al marco provincial y a procesos productivos de narrativas destinadas a la televisión digital.

En estas entrevistas (y en la propia convocatoria de INCAA mencionada) no se invoca una "mirada regional" (como lo hace Segato), sino unas "historias regionales", unos contenidos que merecen y deberían ser contados en aras a descentrar las imágenes de la nación (Nicolosi, 2014), y al mismo tiempo por su posibilidad de autoreferencialidad y por su potencial de denuncia de la desigualdad (en aquello que se narra tanto en términos de los contenidos como en los de las situaciones productivas). En esa concepción, hay "miradas con acento" (cfr. Segato) pero sobre todo existen "historias con acento", por un lado, y "relaciones con acento (local o regional)", por el otro.

(...) en esas cosas [los y las productores del NOA] siempre estuvimos juntos, trabajando juntos y logrando alianzas y participando en foros y en encuentros y entonces... yo creo que fue por una cuestión de cercanía, por una cuestión de vínculo, digamos, y que muchos son aparte compañeros de la Red, son amigos, bueno eso también fortaleció. Como te digo también con otras regiones hemos trabajado codo a codo, en ese sentido. (ArO)

La idea del espacio local productivo como intersección de redes y relaciones sedimentadas y emergentes, constantes y conflictivas, involucra repetidamente la referencia a la región del NOA. Al mismo tiempo, revela que su construcción se asienta parcialmente en los vínculos y proyectos en común generados en los lugares de capacitación por parte de los mismos actores. Es así que los conflictos emergentes en la producción local y entre escalas y espacios referenciales de los sentidos de ciudad de estos 
García Vargas. La puerta de Latinoamérica (desde las rutas Argentinas): San Salvador de Jujuy en geografías...

actores se vinculan a diversos aspectos relacionados al proceso de profesionalización en ámbitos que exceden a la ciudad, y la vinculan y posicionan en un mapa mayor.

El "acento" de estas relaciones se adquiere en el movimiento entre diversos sitios y encuentra una parte central de esa "tonada" en las ciudades que operan como centros de capacitación de los y las productores. Se trata de las localizaciones universitarias o de formación superior, que para el ámbito audiovisual aquí relevado quedan mayoritariamente fuera del NOA. Concretamente, en Córdoba y Buenos Aires.

A su vez, esa "tonada" varía fuertemente en las experiencias autodidactas construidas localmente (aunque quienes así las invocan registran antecedentes formativos en vínculos con otros sitios, desde los cuales "se llega" a San Salvador y a las producciones de las convocatorias INCAA con un "capital profesional audiovisual" -por decirlo de algún modo- ya acumulado).

Parte de esas variaciones en la formación se traducen en miradas discrepantes al interior del mismo sitio de producción, ya que alimentan las posibilidades concretas de realización de los propios actores al incidir en el énfasis que se presta a diferentes dimensiones, en el peso relativo de los aspectos técnicos y narrativos para la propia praxis, y en la definición de los objetivos o derivas éticas y estéticas de cada proyecto.

Los trayectos que abarcan diferentes "porciones" de espacio se trazan predominantemente entre ciudades. De esa manera, la identificación contra otra ciudad se complementa con frecuencia aludiendo a la común pertenencia a un mapa mayor, o bien ese mapa o geografía extensa se construye tomando como referentes a las ciudades. En términos de intersecciones o relaciones entre sitios para definir la propia localización de la producción el guionista de El viaje coincidirá en la importancia del lugar de formación para la constitución de una geografía amplia regional, relativizando en ese caso la cercanía del espacio noroestino para resaltar, en cambio, que el vínculo de su equipo reconoce una historia previa desarrollada en Córdoba (concretamente, en la Escuela de Cine de la Universidad Nacional de Córdoba), donde se formaron varios de los participantes e integrantes de la Fundación Séptimo Arte. Es decir que el lugar de encuentro previo que posibilita en gran medida la emergencia del equipo de $E l$ viaje localizado en San Salvador no corresponde al NOA, sino que alude a otro espacio cultural "mayor". Ese espacio se recorta uniendo a Jujuy (y al NOA en general) con la ciudad de Córdoba, cuya universidad resulta centro formativo de una parte de sus clases medias. En esa "porción" del territorio nacional, Córdoba asume posición de centro para el conjunto de puntos urbanos comprendidos en la dinámica social y cultural que se extiende desde esa urbe hacia el Norte del país (Sorá, 2010). Incluso, en el equipo de El viaje, el único participante "externo" proviene de esa ciudad y de esa universidad:

[A la posproducción] la hicimos acá pero el posproductor era un amigo, un compañero de Córdoba, (...) un gran profesional. (...) Y bueno, había algunos requerimientos técnicos que pedía el Instituto que tenía que ver con el manejo de programas, con la calidad en la que filmábamos (...) acá tenemos varios compañeros que también editan pero este compañero vino 
como a capacitarnos también a nosotros, en cuanto al programa y todas las posibilidades que había. Fue la única persona que vino desde Córdoba junto con otros técnicos, pero que son jujeños, vinieron de allá de la provincia de Córdoba. Pero no, está como íntegramente realizada acá y la mayoría somos jujeños. Queríamos también eso, por una cuestión también de quizás de afinidad. (JoV)

El único realizador cuya narrativa profesional sociobiográfica no incluye un itinerario de duración y espacialización extensas de formación que aluda a las rutas argentinas o a la "exterioridad" latinoamericana es el de Jujuy profundo. Su formación no es sólo local, sino que se narra al interior del marco de relaciones familiares, e incluso se explica genealógicamente:

Aparte vengo de una familia de poetas, mi tío fue poeta, fue vicepresidente de la Academia de Letras, cargo que solamente se hereda cuando uno muere. Mi papá también escribía muy bien y yo fui el peor de todos, soy el peor de todos. (...) Hubiera querido tener el genio y la impronta tanto de mi tío como de mi viejo pero bueno, el periodismo vino un poco a suplir esa faltante de talento para escribir y acá estoy. (FeC)

Ahora bien, los trayectos profesionales de los demás productores y de la productora de programas vincualdos al fomento ofrecen un contraste interesante con los contenidos producidos. En el unitario documental Murmullo los y las protagonistas relatan y describen circuitos de llegada de objetos y/o trayectorias por otros espacios que ubican sus historias de vida en un presente urbano de una provincia argentina vinculado a un pasado en otros espacios, muy diversos: lotes de zafreros en los ingenios azucareros de las Yungas, ciudades de Bolivia, locales de trabajo formal en áreas mejor urbanizadas que las de las ferias. En otros casos, la ciudad y el propio espacio de trabajo en la calle han sido desde el nacimiento uno de los escenarios de esas vidas.

La serie El viaje, a su vez, se estructura en base al movimiento de su protagonista en el corredor que, siguiendo el cauce del Río Grande, habilita la Ruta Nacional $N^{\circ}$ 9 (con un pequeño "desvío" hasta la ciudad de San Pedro), que atraviesa todo el territorio provincial. Gabriel, el personaje, parte de Villazón hacia La Quiaca, ciudad puneña que limita con Bolivia, y recorre la puna, desde el norte hasta la Quebrada de Humahuaca, en su intermedio; sigue hacia San Pedro (desviándose entonces de la Ruta 9 durante un capítulo) y la región del valle hacia el Sur de la provincia, atravesando el conglomerado urbano más grande de Jujuy para luego desplazarse a la ciudad de Salta y llegar a Tucumán (donde ya no está el padre, pero recibe su herencia). Alrededor de esta ruta, que va desde La Quiaca hasta Buenos Aires en su trazado completo, se ubican varias localidades relevantes en la organización del espacio provincial, muchas de ellas cabeceras de departamento, por lo cual ese corredor da cuenta de una organización política, económica y social del territorio vinculada al movimiento constante de bienes 
García Vargas. La puerta de Latinoamérica (desde las rutas Argentinas): San Salvador de Jujuy en geografías...

y personas entre ellas. Pero, además, el trazado de la ruta 9 en el trayecto La QuiacaSan Salvador de Jujuy se superpone con el recorrido histórico del Ferrocarril Belgrano Cargas en torno al cual se articularon los principales poblados de la región (los llamados pueblos del ferrocarril), hasta su desmantelamiento en el año 1993. Esas vías férreas se construyeron, a su vez, siguiendo el principal circuito de intercambio colonial, que retomó uno de los más importantes del período prehispánico (Gil Montero, 2006). Una parte de ese corredor coincide con el circuito de la Quebrada de Humahuaca declarado Patrimonio Histórico de la Humanidad por UNESCO.

A su vez, los capítulos 1 y 2 de la serie Maestros relatan los trayectos geosocio-biográficos de dos grandes escritores. Ernesto Aguirre nació en Jujuy, estudió en Tucumán y volvió a su ciudad natal durante la dictadura. Trajo consigo, de esa estancia en la Universidad Nacional de Tucumán, un programa de radio que rebautizó en Jujuy. Andrés Fidalgo nació en Buenos Aires y se radicó en Jujuy luego de estudiar Derecho en Córdoba. Su carrera profesional se realizó en la capital jujeña, salvo el período del exilio durante la última dictadura.

Los mapas sociobiográficos de los productores y la productora y los de los personajes de los contenidos producidos (pero también los que se reconstruyen en entrevistas con audiencias de barrios populares, tema que no se ha trabajado aquí) coinciden en un presente urbano localizado en la ciudad de San Salvador de Jujuy, pero discrepan notablemente en términos de los trayectos previos. Tanto en el personaje de la ficción como en una parte relevante de quienes brindan testimonio en Murmullo, las geografías extensas se construyen en un camino que va de Norte a Sur (partiendo desde Bolivia o desde las tierras altas de Puna y Quebrada) para llegar a San Salvador, mientras que en el caso de los y las productores -como ocurre con los poetas jujeños de Maestros del Norte (cap. 1 y 2)-, esa geografía en la que se desarrolla la formación y preparación para el trabajo involucra un trayecto que llega a la ciudad desde el sur, o bien que parte desde la ciudad hacia el sur del país en caminos de ida y vuelta que exceden y superan el NOA, involucrando a Córdoba, a Rafaela, a Buenos Aires. ${ }^{13}$

\section{Conclusiones}

Rutas, raíces y rutinas en la constitución del NOA como región audiovisual

Como sostiene Braudel (cit. por Agüero y García, 2010):

Ciudades y rutas, rutas y ciudades, forman un solo y único aspecto del equipo humano del espacio. Cualesquiera que sean su forma, su arquitectura o la civilización que la ilumine, la ciudad es siempre hija del espacio, creadora de rutas $\mathrm{y}$, al mismo tiempo, creada por ellas (16)

\footnotetext{
${ }^{13}$ La coincidencia en la formación "letrada" entre los y la productores audiovisuales "independientes" y "militantes" y los poetas (también militantes) jujeños reafirman la homología entre las apreciaciones de Rama (1998) sobre la ciudad revolucionada y la ciudad mediatizada jujeña, formación intelectual y artística que además se realiza en lugares similares.
} 
El lugar relativo que recibe o disputa la ciudad de San Salvador de Jujuy en una geografía cultural extensa y desigual que alude al contacto y al intercambio -y no (o, al menos, no solamente) a la inmanencia de lo local o a la oposición con sus "otros espaciales" (García Vargas, 2006, 2017)- se materializa en la percepción de las distancias y en las metáforas que se utilizan para describir las intersecciones, mediaciones y continuidades de este específico lugar urbano al interior de mapas de relaciones amplios e históricamente estructurados que combinan la propia experiencia de estar ubicado/a en un sitio preciso con el sentido común sobre las dimensiones y límites de esos mismos mapas, ubicaciones y relaciones.

En las entrevistas con realizadores y realizadoras, esas distancias, cercanías y metáforas se cartografían en diversas escalas, que a su vez se intersectan en los sentidos de ciudad. Concretamente, esos mapas refieren y construyen continuidades y trayectorias que abarcan la provincia de Jujuy, el Noroeste argentino, la Nación argentina, Latinoamérica, el territorio que históricamente ocupara el Alto Perú, y el que actualmente se integra en el Mercosur.

Ese conjunto de relaciones espacializadas alude tanto a localizaciones particulares puestas en relación recíproca, como a trayectos (entendidos como formas particulares del tiempo y el espacio, llenos de sentidos y que llenan de sentidos a las localizaciones particulares) y posiciones intermedias. Refieren tanto al movimiento como a la interdependencia entre estos sitios, en tanto parte de las relaciones cotidianas, emergentes y sedimentadas que producen (a su vez) el espacio urbano. Esas cartografías superpuestas que explican el propio lugar se construyen a partir de la ubicación y peso relativos que se otorgan a San Salvador de Jujuy dentro de espacios amplios, en relación a diversos centros, orígenes o cruces de caminos. Se evidencian como itinerarios de las socio-biografías, de las rutinas productivas, de las prácticas de formación para el trabajo, y de la estabilización e institucionalización de relaciones y redes vinculadas a ambos aspectos. Se trata de mapas que reúnen rutas, raíces y rutinas (Gilroy, 1993; Román Velázquez, 1999).

El análisis muestra tres maneras principales de referencia a esos espacios extensos en los sentidos de ciudad: las geografías mayores de San Salvador de Jujuy, cuando se interrogan a partir de las prácticas productivas audiovisuales locales, se estructuran en base a la idea de la ciudad como punto de articulación o traducción entre dos o más espacios amplios; sobre la referencia a una posición inequitativa en equilibrios desiguales establecidos en base a centros y periferias; o considerando a la ciudad como punto de un camino o itinerario (de personas, objetos, referencias, recursos, situaciones o imágenes).

El otro espacial constituido por el conjunto de ciudades argentinas aparece como una selección de rasgos modélicos de los que San Salvador de Jujuy se aparta. Esos rasgos refieren tanto a la dinámica de la producción cultural (el "capital audiovisual" y las posibilidades de audiovisualizar) como a las características que se predican estereotípicamente de lo urbano-argentino. Esas posibilidades de identificación por oposición se complementan con la actualidad de las posibilidades abiertas por la 
García Vargas. La puerta de Latinoamérica (desde las rutas Argentinas): San Salvador de Jujuy en geografías...

coexistencia de esos mismos puntos para constituir geografías amplias que también brindan sentido a la ciudad, ya no como otros contra los cuales identificarse sino como aquellos que posibilitan unas formas específicas de convivencia espacial que alimentan la experiencia de la ciudad como intersección culturalmente productiva. Esas modalidades de los mapas amplios de la producción cultural se producen en distintas escalas, son parte de las biografías profesionales de realizadores y realizadora y también son parte de las historias de vida de los escritores y de los paisajes audiovisuales que retoman o proponen los programas locales. La ciudad es, en ese juego, escala, puerta, parte de caminos y componente de regiones que le dan forma ya no por oposición sino por continuidad. Esto es, la ciudad articula o es articulada en espacios amplios que estructuran la producción audiovisual pero también los paisajes nacionales y globales del turismo y el intercambio cultural.

Entre esas opciones, la imagen de la puerta brinda centralidad en el espacio del margen, porque la ciudad se vuelve lugar principal de regulación del acceso o del encuentro en una configuración espacial de la interculturalidad que la organiza a partir de los límites nacionales. Esto es, la ciudad resulta punto de intermediación entre dos marcos diversos de producción y gestión del espacio urbano que intersectan en ella. Como puerta, lugar de pasaje, punto de contacto, San Salvador pide luz cenital para pensar audiovisualmente la articulación latinoamericana -vía el mundo andino o la nación boliviana- desde Argentina.

Como sostienen Fernanda Areas Peixoto y Adrián Gorelik (2016) la ciudad, en tanto arena cultural "es lugar de germinación, de experimentación y de combate cultural" (11). Este lugar, si se quiere novedoso, que muestra a la ciudad en su carácter de arena cultural (audiovisual) que espacializa un proceso productivo articulatorio remite a la centralidad perdida que se reclama en clave política en Jujuy Profundo y a la participación nacional en igualdad pedida por audiovisualistas independientes y militantes cuando solicitan la distribución de fondos productivos. Aunque con relativas posibilidades de incidencia en una u otra geografia extensa, esta ciudad participa a través de la audiovisualización y las audiovisualidades en el mosaico regulado nacionalmente de las regiones INCAA. En ese contexto, San Salvador de Jujuy puede ser imaginada como enclave civilizatorio audiovisual en tanto "ciudad mediatizada" (Paiva y Sodré, 2005).

Como arena cultural, entonces, también se superpone productivamente a las geografías amplias que delinean relaciones profesionales con acento para la ciudad mediatizada, si tal acento corresponde al lugar de formación de realizadores y realizadoras, o los reúne para reivindicaciones comunes en el contexto noroestino. Y ese acento regional participa en igualdad con los demás acentos regionales, en tanto el NOA es un fragmento espacial constituyente del mapa-mosaico del INCAA asociado a las políticas federales de fomento junto a las demás regiones argentinas, en momentánea situación de equivalencia durante el período del trabajo de campo.

Productores y productoras privilegian a ciudades del NOA (como Salta o Tucumán) y a las mismas urbes que formaron parte del trayecto formativo como referencias para las propias prácticas y también para comparar y postular planes a futuro. 
Aunque, al mismo tiempo y de manera reiterada, la esencia o el caos alucinante se busquen en el espacio andino de Latinoamérica: las historias que merecen ser contadas (y filmadas) refieren de manera continua a ese espacio paradigmático del territorio jujeño, tan afectiva y efectivamente reconocible en la economía simbólica nacional, provincial y global como el sitio por excelencia de la "aboriginalidad" (en su estricto sentido de origen que lo vincula a la Pachamama). No sin conflictos, ese mundo se combina con la idea de Jujuy como "kilómetro cero" espacial y temporal de la patria en las luchas por la Independencia Nacional. En ambos casos, se produce un espacio que adquiere significación en el pasado y que le brinda sentido a la ciudad en el presente y hacia el futuro, ubicándola en una región que combina la pertenencia regional andina a la del Noroeste Argentino. En ese ejercicio, se producen una topología social y una cartografía que otorgan poder de manera sistemáticamente desigual a los diversos productores que la audiovisualizan y a los diferentes grupos que son audiovisualizados.

\section{Referencias bibliográficas}

Abu Lughod, L. (2006) Interpretando la(s) cultura(s) después de la televisión: sobre el método. Íconos (24), 119-141.

Agüero, A. C. y García, D. (2010) Introducción. En A. C. Agüero y D. García (Ed.): Culturas interiores: Córdoba en la geografía nacional e internacional de la cultura (15-28). La Plata, Argentina: Al margen.

Aguilar, G. (1999) “Televisión y vida privada”, en Devoto, Fernando y Marta Madero (dir.): Historia de la vida privada en la Argentina, Buenos Aires, Taurus. Tomo 3.

Antezana, L. (2009) Dos conceptos en la obra de René Zavaleta Mercado: Formación abigarrada y democracia como autodeterminación. En L. Olivé, B. de Sousa Santos, C. Salazar de la Torre, L. H. Antezana, W. Navia Romero, L. Tapia, G. Valencia García, M. Puchet Anyul, M. Gil, M. Aguiluz Ibargüen y H. J. Suárez, (2009) Pluralismo epistemológico. CLACSO Coediciones. La Paz: CLACSO Muela del Diablo Editores- Comunas - CIDES - UMSA.

Briones, C. (2005) Cartografias argentinas: politicas indigenistas y formaciones provinciales de alteridad. Buenos Aires, Argentina: Antropofagia.

Briones, C. (2008) Diversidad cultural e interculturalidad: ¿de qué estamos hablando? En C. García Vázquez (Comp.), Hegemonía e interculturalidad. Poblaciones originarias y migrantes (pp. 35-58). Buenos Aires, Argentina: Prometeo.

Burgos, R. (2014) Fútbol y política. El club Gimnasia y Esgrima y la construcción de una identidad jujeña (1975-2011). Tesis de Doctorado en Comunicación, Universidad Nacional de La Plata.

Burgos, R. y García Vargas, A. (2008) El irrenunciable desafío de trabajar por Jujuy y su gente. Actores, cultura e identidad en el suplemento '50 aniversario de Pregón'. Oficios terrestres, 21, 80-91

Caggiano, S. (2005). Lo que no entra en el crisol. Buenos Aires, Argentina, Prometeo. 
Caggiano, S. (2012). El sentido común visual. Disputas visuales en torno a género, "raza" y clase en imágenes de circulación pública. Buenos Aires, Argentina: Miño y Dávila.

Calvetti, F. (2012): Jujuy Profundo. 5ta Temporada [magazine cultural para televisión]. San Salvador de Jujuy: FeC / Canal 4.

Carman, M. (2006). Las trampas de la cultura. Los "intrusos" y los nuevos usos del barrio de Gardel. Buenos Aires, Argentina: Paidós.

Gaona, M. (2015). Experiencia popular, ciudad e identidad en el Noroeste Argentino. La organización social Tupac Amaru. Oxford, Reino Unido: Peter Lang.

Garcia Canclini, N. (1990). Culturas Hibridas: Estrategias para entrar y salir de la modernidad. México DF, México: Grijalbo.

García Vargas, A. (2006). En construcción. Geografías del poder y sentidos del lugar en San Salvador de Jujuy. UNIREV 1 (s/p.)

García Vargas, A. (2009). "La desigualdad a la vuelta de la esquina. San Salvador de Jujuy durante la década de 1990". En Lagos, Marcelo (director): Jujuy bajo el signo neoliberal. San Salvador de Jujuy, Argentina: EDIUNJu. Pp. 357-399.

García Vargas, A. (2014). Mapas comunicacionales y territorios de la experiencia. Notas espaciales sobre San Salvador de Jujuy, Murmullo que aturde. En A. P. Nicolosi (Comp.): La televisión en la década kirchnerista. Democracia audiovisual y batalla cultural (163-184). Buenos Aires, Argentina: Universidad Nacional de Quilmes.

García Vargas, A. (2015). Dinámicas de la comunicación para el cambio social en coyuntura: el caso de Wayruro Comunicación Popular (Jujuy, NOA, 19942014). En E. Nos Aldás, A. I. Arévalo Salinas y A. Farné (Ed.), \#comunicambio: Comunicación y Sociedad Civil para el cambio social (399-410). Madrid, España: Fragua.

García Vargas, A. (2017). Producción social del espacio y configuraciones culturales. Sentidos de ciudad en narativas audiovisuales contemporáneas de San Salvador de Jujuy. Tesis doctoral en Comunicación. Córdoba, Argentina: Universidad Nacional de Córdoba.

Gilder, George (1994). Life after Television. The Coming Tranformation on Media and American Life. New York, Estados Unidos: Norton.

Gilroy, P. (1993). The Black Atlantic: Modernity and Double Counsciousness. Londres, Reino Unido: Verso.

Grimson, A. y Caggiano, S. (2015). Introducción. Los pensamientos críticos argentinos. En S. Caggiano y A. Grimson (Ed.): Antología del pensamiento crítico argentino contemporáneo (11-31). Buenos Aires, Argentina: CLACSO.

Grimson, A. y Karasik, G. (Coord.) (2017). Estudios sobre la diversidad sociocultural en la Argentina Contemporánea.

Grossberg, Lawrence (1996): "The space of culture, the power of space", en Chambers, Iain y Lidia Curti (eds.): The postcolonial question. Common skies, divided horizons. Londres, Routledge. Traducción mía. 
Grossberg, Lawrence (2012): Estudios culturales en tiempo futuro. Cómo es el trabajo intelectual que require el mundo de hoy. Buenos Aires, Siglo XXI.

Hall, Stuart y Mellino, Miguel (2011): "La cultura y el poder. Conversaciones sobre los Cultural Studies". Buenos Aires, Amorrortu.

Jaguaribe, B. (2016). Río de Janeiro. La ciudad mediática: telenovelas y mundo urbano. En A. Gorelik y F. Arëas Peixoto (Comp.) Ciudades sudamericanas como arenas culturales (424-439). Buenos Aires, Argentina: Siglo XXI.

Karasik, G. (ms). Etnicidad, cultura y clases sociales. Procesos de formación histórica de la conciencia colectiva en Jujuy, 1970-2003. (Tesis de Doctorado en Ciencias Sociales). Universidad Nacional de Tucumán, San Miguel de Tucumán. 2005.

Lefebvre, H. (2013). La producción del espacio. Madrid, España: Capitán Swing. Traducción de Emilio Martínez

Ley de Servicios de Comunicación Audiovisual. Ley N²6.522 (Senado de la Nación Argentina, 10 de octubre de 2009). Regúlanse los Servicios de Comunicación Audiovisual en todo el ámbito territorial de la República Argentina. Boletín Oficial de la República Argentina, año CXVII, No 31.756. Recuperado de http:// www.boletinoficial.gov.ar/Inicio/Index.castle.

Lindón, A. (2008). Los giros de la geografía urbana: frente a la pantópolis, la microgeografía urbana. Scripta Nova, XII, 270 (62). Recuperado de http:/www. ub.edu/geocrit/-xcol/81.htm.

Manzanal, M. (1999). La cuestión regional en la Argentina de fin de siglo, Realidad Económica, (166), 70-99.

Massey, D. (1979). In what sense a regional problem? Regional Studies, 13, 233-243. Mi traducción.

Massey, D. (1995). The conceptualization of place. En D. Massey y P. Jess (Ed.), A place in the World? Places, culture and Globalizaton (45-85). Oxford, Gran Bretaña, Oxford University Press/Open University. Mi traducción.

Massey, D. (2005a). For Space. Londres, Gran Bretaña: SAGE. Mi traducción.

Massey, D. y Jess, P. (Ed.). (1995) A place in the World? Places, culture and Globalizaton. Oxford, Gran Bretaña, Oxford University Press/Open University. Mi traducción. Negroponte, N. (1995). Ser digital. Buenos Aires, Argentina: Atlántida.

Nicolosi, A. P. (2014) La ficción televisiva a partir de la LSCA. "Des-centrando" la producción y la empleabilidad técnica. En A. P. Nicolosi (Comp.), La televisión en la década kirchnerista. Democracia audiovisual y batalla cultural (47-62). Buenos Aires, Argentina: Universidad Nacional de Quilmes.

Ogando,A.(director) (2011): Maestros del Norte. San Salvador de Jujuy [serie documental federal para televisión]. San Salvador de Jujuy: Wayruro Comunicación Popular/ INCAA.

Paiva, R. y Sodré, M. (2004) Cidade dos artistas. Cartografia da televisãoe da fama no Rio de Janeiro. Río de Janeiro, Brasil: Mauad.

Papalini, V. (2010) Hermenéutica crítica: apuntes y reflexiones para la investigación en Comunicación. En C. Arrueta, M. Brunet y J. Guzmán (Comp.), La Comunicación como objeto de estudio (95-130). Jujuy, Argentina: Editorial UCSE. 
Rabey, M. y Jerez, O. (eds.) (2000) Procesos de urbanización en la Argentina: La mirada Antropológica. San Salvador de Jujuy, Argentina: EDIUNJu.

Rama, A. (1998) La ciudad letrada. Montevideo, Uruguay: Arca.

Ricciardi, Diego (director) (2011) San Salvador de Jujuy, Murmullo que aturde [unitario documental federal para televisión] San Salvador de Jujuy, Wayruro Comunicación Popular/INCAA.

Rivera Cusicanqui, S. (2010) Ch'ixinakaxUtxiwa. Una reflexión sobre prácticas y discursos descolonizadores, Buenos Aires, Argentina, Tinta Limón.

Román Velázquez, P. (1999) The making of Latin London. Salsa music, place and identity, Londres, Gran Bretaña: Ashgate.

Romero, J. L. (2001) Latinoamérica: las ciudades y sus ideas. Buenos Aires, Argentina: Siglo XXI.

Romero, M. A. (2010). Estética y orden como sinónimos de belleza. El caso de la ciudad de San Salvador. En A. García Vargas (comp.), San Salvador de Jujuy como texto: imágenes y relatos de la ciudad (31-40). San Salvador de Jujuy: EdiUnju

Rose, G. (1995). Place and identity: a sense of place. En D. Massey y P. Jess (Ed.). (1995) A place in the World? Places, culture and Globalizaton (87-132). Oxford, Gran Bretaña: Oxford University Press \& Open University.

Segato, R. (2007) La Nación y sus Otros. Raza, etnicidad y diversidad religiosa en tiempos de Políticas de la Identidad. Buenos Aires, Argentina: Prometeo.

Sautu, R. (2005) Todo es teoría. Objetivos y métodos de investigación. Buenos Aires, Argentina: Lumiere.

Segura, R. (2015) Vivir afuera. Antropología de la experiencia urbana, San Martín, Buenos Aires, UNSAM.

Sorá, G. (2010) Prólogo. Interiorizar y objetivar, o la centralidad de la periferia cordobesa. En A. C. Agüero y D. García (Ed.), Culturas interiores: Córdoba en la geografía nacional e internacional de la cultura (11-14). La Plata, Argentina: Al margen.

Troncoso, C. A (2009). El retrato cambiante de la Quebrada de Humahuaca. Transformaciones y permanencias en sus atractivos turísticos. En R. Bertoncello, Turismo y Geografia (17-42). Buenos Aires, Argentina: La Crujía.

Vargas, Jorge (director) (2011): El viaje, 9 días buscando Norte [serie de ficción federal para televisión]. San Salvador de Jujuy: Fundación Séptimo Arte/INCAA. 


\section{ANEXO}

Tabla sintética de características generales de los programas del corpus

\begin{tabular}{|c|c|c|c|c|}
\hline PROGRAMA & $\begin{array}{c}\text { Jujuy Profundo } \\
\text { (JP) }\end{array}$ & $\begin{array}{c}\text { San Salvador de } \\
\text { Jujuy, Murmullo } \\
\text { que aturde (M) }\end{array}$ & $\begin{array}{c}\text { El viaje. } 9 \text { días } \\
\text { buscando Norte } \\
\text { (V) }\end{array}$ & $\begin{array}{l}\text { Maestros del } \\
\text { Norte (MN) }\end{array}$ \\
\hline Género & $\begin{array}{l}\text { Revista semanal pe- } \\
\text { riodístico - cultural }\end{array}$ & $\begin{array}{l}\text { Unitario docu- } \\
\text { mental }\end{array}$ & Serie de ficción & $\begin{array}{l}\text { Serie documen- } \\
\text { tal de cuatro } \\
\text { capítulos }\end{array}$ \\
\hline $\begin{array}{l}\text { Realizador/es/as } \\
\text { entrevistados/as }\end{array}$ & $\begin{array}{l}\text { FeC (conductor y } \\
\text { realizador integral } \\
\text { del ciclo) }\end{array}$ & $\begin{array}{l}\text { DiR (director y } \\
\text { guionista) } \\
\text { ArO (productor } \\
\text { general) } \\
\text { PaK (asistente de } \\
\text { producción, de } \\
\text { guión y de sonido; } \\
\text { foto fija) }\end{array}$ & $\begin{array}{l}\text { JoV (director) } \\
\mathrm{FeB} \text { (guionista) }\end{array}$ & $\begin{array}{l}\text { ArO (director y } \\
\text { guionista de la } \\
\text { serie; director } \\
\text { del capítulo 2) } \\
\text { DiR (productor } \\
\text { general) } \\
\text { PaK (produc- } \\
\text { tora ) }\end{array}$ \\
\hline Financiamiento & $\begin{array}{l}\text { Auto-gestivo, por } \\
\text { pauta publicitaria } \\
\text { local }\end{array}$ & $\begin{array}{l}\text { INCAA POPFCAD } \\
\text { Convocatoria Fede- } \\
\text { ral } 2010 \text { Modali- } \\
\text { dad: unitarios docu- } \\
\text { mentales federales } \\
\text { "Nosotros" / Jujuy }\end{array}$ & $\begin{array}{l}\text { INCAA POP- } \\
\text { FCAD Convo- } \\
\text { catoria Federal } \\
2010 \\
\text { Modalidad: Fic- } \\
\text { ciones federales / } \\
\text { Región NOA }\end{array}$ & $\begin{array}{l}\text { INCAA POP- } \\
\text { FCAD Convo- } \\
\text { catoria Federal } \\
2010 \\
\text { Modalidad: } \\
\text { Series Documen- } \\
\text { tales Federales / } \\
\text { Región NOA }\end{array}$ \\
\hline \multirow[t]{4}{*}{$\begin{array}{l}\text { Distribución } \\
\text { (canal que lo } \\
\text { emite, plataforma } \\
\text { que lo aloja } \\
\text { y/o exhibición } \\
\text { alternativa) }\end{array}$} & Canal 4 Jujuy & $\begin{array}{l}\text { BACUA } \\
\text { Plataforma CDA } \\
(2012-2015) \\
\text { Exhibición en } \\
\text { muestras audiovi- } \\
\text { suales }\end{array}$ & $\begin{array}{l}\text { Canal } 7 \text { de } \\
\text { Jujuy (televisión } \\
\text { abierta local de } \\
\text { alcance provin- } \\
\text { cial, disponible } \\
\text { en los dos servi- } \\
\text { cios de televisión } \\
\text { por cable de la } \\
\text { ciudad) } \\
\text { BACUA }\end{array}$ & $\begin{array}{l}\text { Canal Encuentro } \\
\text { (señal disponible } \\
\text { en la grilla de } \\
\text { TDA con alcance } \\
\text { nacional y en los } \\
\text { dos servicios de } \\
\text { televisión por ca- } \\
\text { ble de la ciudad) } \\
\text { / Junio de } 2012\end{array}$ \\
\hline & & & & BACUA \\
\hline & & & $\begin{array}{l}\text { Plataforma CDA } \\
\text { 2012-2016 }\end{array}$ & $\begin{array}{l}\text { Plataforma CDA } \\
(2012-2016)\end{array}$ \\
\hline & & & $\begin{array}{l}\text { Exhibición de } \\
\text { versión sintética } \\
\text { en programación } \\
\text { especial de Tea- } \\
\text { tro Mitre (avant } \\
\text { premiere) }\end{array}$ & $\begin{array}{l}\text { Exhibición de } \\
\text { la serie com- } \\
\text { pleta en Jujuy } \\
\text { cortos } 2013 \text { y del } \\
\text { capítulo } 1 \text { en al } \\
\text { Itinerancia Jujuy } \\
\text { de la II Muestra } \\
\text { Ciudades Reve- } \\
\text { ladas (2016) }\end{array}$ \\
\hline
\end{tabular}


DOSSIER

García Vargas. La puerta de Latinoamérica (desde las rutas Argentinas): San Salvador de Jujuy en geografías...

\begin{tabular}{|c|c|c|c|c|}
\hline Año de realización & 2012 & 2011 & 2011 & 2011 \\
\hline $\begin{array}{l}\text { Año de estreno y } \\
\text { canal o plataforma }\end{array}$ & 2008 Canal 4 & $\begin{array}{l}2012 \text { Plataforma } \\
\text { CDA }\end{array}$ & $\begin{array}{l}2012 \text { Canal } 10 \\
\text { Tucumán } \\
2012 \text { Colsecor } \\
2012 \text { Canal } \\
\text { Cooperativo de } \\
\text { Neuquén } \\
2013 \text { Canal } 7 \text { de } \\
\text { Jujuy }\end{array}$ & $\begin{array}{l}2012 \text { Canal En- } \\
\text { cuentro }\end{array}$ \\
\hline $\begin{array}{l}\text { Lugar de } \\
\text { realización }\end{array}$ & $\begin{array}{l}\text { San Salvador de } \\
\text { Jujuy }\end{array}$ & $\begin{array}{l}\text { San Salvador de } \\
\text { Jujuy }\end{array}$ & $\begin{array}{l}\text { San Salvador de } \\
\text { Jujuy }\end{array}$ & $\begin{array}{l}\text { San Salvador de } \\
\text { Jujuy }\end{array}$ \\
\hline $\begin{array}{l}\text { Sinopsis o } \\
\text { presentación } \\
\text { publicada para } \\
\text { difusión }\end{array}$ & $\begin{array}{l}\text { La historia está } \\
\text { hecha para ser } \\
\text { contada! (sic) Y qué } \\
\text { mejor que apren- } \\
\text { derla de la mano } \\
\text { de especialistas en } \\
\text { la materia, "Jujuy } \\
\text { Profundo" es un } \\
\text { programa que te } \\
\text { permitirá conocer } \\
\text { la rica historia de } \\
\text { nuestro terruño, re- } \\
\text { memorando hechos, } \\
\text { fechas y aconteci- } \\
\text { mientos que fueron } \\
\text { importantes para la } \\
\text { patria pero también } \\
\text { para forjar nues- } \\
\text { tro camino como } \\
\text { provincia }\end{array}$ & $\begin{array}{l}\text { Las fachadas } \\
\text { barrocas de San } \\
\text { Salvador de Jujuy, } \\
\text { en conjunto con las } \\
\text { artesanías en cerá- } \\
\text { mica y coloridos } \\
\text { tejidos que rebalsan } \\
\text { de las tiendas } \\
\text { remontan a su pa- } \\
\text { sado pre-incaico así } \\
\text { como a la colonia } \\
\text { española. Así es } \\
\text { como esta ciudad } \\
\text { cautiva a miles de } \\
\text { turistas ávidos de } \\
\text { relatos románticos } \\
\text { de dichas épocas. } \\
\text { Estos de alguna } \\
\text { manera ocultan los } \\
\text { conflictos actuales } \\
\text { que conforman la } \\
\text { verdadera identidad } \\
\text { de la ciudad. } \\
\text { Hoy se imponen los } \\
\text { que ganaron, pero } \\
\text { los otros están, } \\
\text { siempre creando } \\
\text { nuevas formas de } \\
\text { representatividad, } \\
\text { en un murmullo } \\
\text { constante, casi } \\
\text { silencioso, pero que } \\
\text { en realidad aturde. }\end{array}$ & $\begin{array}{l}\text { Solo y casi sin } \\
\text { esperanzas, } \\
\text { Gabriel em- } \\
\text { prende un viaje } \\
\text { a la Argentina } \\
\text { en busca de su } \\
\text { familia. La serie } \\
\text { es un relato que } \\
\text { nos introduce en } \\
\text { el temperamento } \\
\text { de los habitantes } \\
\text { de los pueblos de } \\
\text { frontera, su mira- } \\
\text { da sobre la vida } \\
\text { en la inmensidad } \\
\text { del paisaje y sus } \\
\text { aspiraciones a } \\
\text { una vida mejor } \\
\text { en la ciudad. }\end{array}$ & $\begin{array}{l}\text { Vida y obra de } \\
\text { cuatro escritores } \\
\text { del noroeste } \\
\text { argentino: } \\
\text { Ernesto Aguirre, } \\
\text { Andrés Hidalgo, } \\
\text { Eduardo Perrone } \\
\text { y Luis Franco. } \\
\text { Palabras clave } \\
\text { en plataforma de } \\
\text { Encuentro: Lite- } \\
\text { ratura / Escritor } \\
\text { / Literatura ar- } \\
\text { gentina / Escritor } \\
\text { argentino }\end{array}$ \\
\hline
\end{tabular}

